\title{
ÚLOHA NEMECKA V DREVÁRSKOM PRIEMYSLE SLOVENSKA 1939 - 1945 INŠTITUCIONÁLNY VÝVOJ A OBCHOD S DREVOM
}

\author{
L'UDOVÍT H A L L O N - PETER M I Č K O - MIROSLAV S A B O L
}

\begin{abstract}
HALLON, L'udovít - MIČKO, Peter - SABOL, Miroslav. The role of Germany in the Slovak timber industry, 1939-1945. The institutional development of the timber trade. Historický časopis, 2019, 67, 2, pp. 289-310, Bratislava.

The forestry and timber industry had strategic importance in Slovak - German economic relations in the period 1939-1945. Supplies of unprocessed logs had an important role, but also the products of the Slovak timber processing industry. Slovak-German relations developed in the sphere of the timber and timber processing trade. About $70-80 \%$ of all Slovak exports of timber and timber products went to the territory of the German Reich, including the Protectorate of Bohemia and Moravia. However, in spite of German pressure, the Slovak national economists succeeded in gradually reducing timber exports to Germany and organizing exports to other countries at more advantageous prices.

Key words: Slovakia. Germany. Relations. Trade. Timber. Timber products. Prices.
\end{abstract}

\section{DOI: https://doi.org/10.31577/histcaso.2019.67.2.5}

Lesné hospodárstvo a drevársky priemysel mali v hospodárskych vzt'ahoch Slovenska s nacistickým Nemeckom počas rokov 1939 - 1945 strategický význam. Slovenské drevárstvo figurovalo na popredných miestach hospodárskych plánov Nemeckej ríše vo vzt’ahu k strednej a juhovýchodnej Európe už od polovice 30. rokov. Dôležitú úlohu zohrávali dodávky surovej gul'atiny, ako aj export výrobkov slovenského drevárstva do Nemecka, či už vo forme piliarskych polotovarov a hotových produktov, alebo v podobe chemicky spracovaného dreva. Slovensko-nemecké vzt’ahy na poli drevárstva sa rozvíjali v dvoch hlavných smeroch, a to vo sfére obchodu s drevom a v oblasti drevárskeho priemyslu, kam postupne prenikal ríšsko-nemecký kapitál. Nasledujúca štúdia hodnotí uvedené smery ekonomických vzt’ahov Slovenskej republiky 1939 - 1945 a Nemeckej ríše na pozadí širších súvislostí hospodárskeho vývoja strednej Európy, kde Nemecko presadzovalo plány vel'kopriestorového hospodárstva. Sledované témy boli vzhl'adom na dôležitú úlohu drevárstva počas vojnových rokov čiastočne spracované v niekol'kých štúdiách a monografiách s problematikou hospodárskych dejín Slovenska 1939 - 1945. Čiastočne ich spracoval napríklad historik 
L. Lipták v priekopníckej monografii o úlohe nemeckého kapitálu v priemysle Slovenského štátu z roka 1960. Priekopnícky charakter mala aj doteraz jediná práca osobitne zameraná na slovenské drevárstvo 1939 - 1945 v podobe štúdie lesného odborníka Š. Lángoša z polovice 60. rokov. Uvedená tematika je do určitej miery obsiahnutá aj v prácach J. Faltusa, V. Průchu a L. Suška zo 60. a 70. rokov. Po dlhšej odmlke v 80. rokoch sa začala opät' objavovat' v historiografii z obdobia po roku 1989. Na väčšej ploche ju spracovali napríklad P. Mičko a L. Hallon. Osobitným spôsobom hodnotí danú tematiku jeden z hlavných aktérov dobového hospodársko-politického života, bývalý minister hospodárstva G. Medrický vo svojich memoároch z druhej polovice 20 . storočia. ${ }^{1}$ Predkladaná štúdia, rozdelená do dvoch častí, nadväzuje na doterajšie výsledky slovenskej historiografie v predmetnej oblasti a zároveň ich rozširuje o nové poznatky získané rozsiahlym štúdiom viacerých fondov v zahraničných i domácich archívoch. Ide najmä o fond Ríšskeho lesného úradu (Reichsforstamt) v Spolkovom archíve v Berlíne (Bundesarchiv Berlin) a fond nemeckého vyslanectva v Bratislave (Gesandschaft Preßburg) v Politickom archíve Zahraničného úradu v Berlíne (Politisches Archiv des Auswertigen Amtes Berlin), ale aj o fondy Slovenského národného archívu, Archívu Národnej banky Slovenska a niektorých regionálnych archívov. Štúdia trojice autorov napriek väčšiemu rozsahu zd'aleka nevyčerpáva celý obsah vytýčených hlavných tém, ale má za ciel' najmä poukázat' na nové skutočnosti a priniest' nové hodnotenia sledovanej problematiky.

V medzivojnovom Nemecku sa už od prelomu 20. a 30. rokov formovala idea budovania hospodárskeho vel'kopriestoru, ktorý by zahŕňal územie celej strednej a juhovýchodnej Európy. Tento priestor pod hospodársko-politickou hegemóniou Nemecka mal byt' ekonomicky sebestačný a $\mathrm{v}$ jeho rámci mali jednotlivé štáty strednej a juhovýchodnej Európy plnit' úlohu dodávatel'ov potravín, surovín a polotovarov ako tzv. doplnkové hospodárske priestory. Po nástupe nacistov

1 K sledovanej problematike pozri napríklad nasledujúce práce: LIPTÁK, Lubomier. Ovládnutie slovenského priemyslu nemeckým kapitálom. Bratislava: Vydavatel'stvo Slovenskej akadémie vied, 1960; LÁNGOŠ, Štefan. Ťažba dreva, drevársky priemysel a obchod s drevom za slovenského štátu. In Zborník prác lesníckeho a drevárskeho múzea 4. Lesnícke a drevárske múzeum v Antole, 1966; FALTUS, Jozef - PRŮCHA, Václav. Prehl’ad hospodárskeho vývoja na Slovensku v rokoch 1918 - 1945. Bratislava: Vydavatel'stvo politickej literatúry, 1969; SUŠKO, Ladislav. Počiatky hospodárskej exploatácie Slovenska nacizmom (marec 1939 júl 1940). In Československý časopis historický, 1977, roč. 25, č. 5, s. 682-714; MIČKO, Peter. Nemecký finančný kapitál a stredné Slovensko v rokoch 1939 - 1945. Banská Bystrica: Ústav vedy a výskumu UMB, 2006. ISBN 808083282; MIČKO, Peter. Hospodárska politika Slovenského štátu. Kapitoly z hospodárskych dejín Slovenska v rokoch 1938 - 1945. Krakov: Spolok Slovákov v Pol'sku, 2014. ISBN 9788089567744; HALLON, L’udovít. Slovensko v hospodárskom priestore Nemecka 1939 - 1945 (rokovania, prehl'ady, sondy, prípadové štúdie). Bratislava: Veda, 2015. ISBN 9788022414654; MEDRICKÝ, Gejza. V práci za povznesenie národa. Spomienky ministra hospodárstva Slovenskej republiky 1939 - 1945. Bratislava: Post Scriptum, s.r.o., 2017. ISBN 9788089567744. 
k moci v roku 1933 si myšlienku hospodárskeho vel'kopriestoru osvojili aj národohospodári ideologicky spojení s novým totalitným režimom. Na ich čele stál Hermann Göring vo funkcii šéfa Úradu pre štvorročný plán. Ďalší organizátor nemeckého hospodárskeho života po roku 1933 guvernér Ríšskej banky Hjalmar Schacht prevzal koncepciu budovania hospodárskeho vel'kopriestoru, respektíve nemeckej vel'kopriestorovej ekonomiky, do Nového plánu hospodárskeho rozvoja Nemecka na prekonanie krízy a naštartovanie ekonomického rastu. Následne rozvinul aj teóriu doplnkových hospodárskych priestorov. ${ }^{2}$

Nacistické Nemecko v druhej polovici 30. rokov postupne prehlbovalo hospodársky vplyv v krajinách strednej a juhovýchodnej Európy. Nemeckí národohospodári tu vytvorili systém ekonomických vzt’ahov založený na dvojstranných hospodárskych zmluvách, pevne stanovených kontingentoch dodávok tovarov a na bezhotovostnom clearingovom zúčtovaní tovarového a platobného styku. Zložitý systém zmlúv a dohôd zabezpečoval Nemecku dodávky strategických surovín, predovšetkým nedostatkovej ropy, farebných kovov, železnej rudy, dreva a pol’nohospodárskych produktov. Zároveň umožňoval realizáciu rozvojových hospodárskych programov pre jednotlivé krajiny sledovaného regiónu, ktoré však boli formované v zmysle ekonomických potrieb Nemecka. Ohl'adne dodávok antimónu, magnezitu, potravín a dreva bolo pre nemeckých národohospodárov zaujímavé aj územie dnešného Slovenska. Už pred rokom 1939 ho začali vnímat' ako špecifický hospodársky celok s úlohou osobitného doplnkového hospodárskeho priestoru Nemecka. ${ }^{3}$ Každá oblast' tovarových alebo iných hospodárskych vzt'ahov v rámci postupne sa formujúcej vel'kopriestorovej ekonomiky Nemecka bola organizačne a inštitucionálne zastrešená a vyvíjala sa na základe dlhodobého plánu. Napríklad kl'účová oblast' ropného hospodárstva bola organizovaná podl'a dvoch druhov plánov z roka 1936. Jeden z nich slúžil na usmerňovanie spotreby ropy $\mathrm{v}$ mierových podmienkach (N-Fall - normálny plán) a druhý na vojnové potreby (Mob.-Fall - mobilizačný plán) s výhl'adom až do roka $1942 .{ }^{4}$

2 K vývoju koncepcií nemeckého vel'kopriestorového hospodárstva pozri: KAHRS, Horst. Von der „Grossraumwirtschaft“ zur „Neuen Ordnung“. Zur strategischen Orientierung der deutschen Eilten 1932-1943. In Modelle für ein deutsches Europa. Ökonomie und Herrschaft im Grosswirtschaftsraum. Beiträge zur nationalsozialistischen Gesundheits-und Sozialpolitik: 10. Berlin: Rotbuch Verlag, 1992, s. 9-28. ISBN 3880229597.

Ku koncepciám H. Schachta vo vzt’ahu k juhovýchodnej Európe pozri napríklad: KOPPER, Christopher. Hjalmar Schacht Aufstieg und Fall von Hitlers mächtigstem Bankier. Mníchov: Deutschen Taschenbuchverlag, 2010, s. 295-305. ISBN 9783423346085.

3 SUNDHAUSEN, Holm. Wirtschaftsgeschichte Kroatiens im nationalsotialistischen Grossraum 1941-1945. Die Scheitern einer Ausbeutungsstrategie. Stuttgart: Deutsche Verlags-Anstalt, 1983, s. 24-26. ISBN 3421061505.

4 Bundesarchiv (d’alej BArch) Berlin, fond (d’alej f.) R 3112/13, s. 1-3, príloha č. 2. Podklady na prednášku pre pol'ného maršála H. Göringa o stanovení ciel'ov a podpore d'alšieho rozvoja 
Pre segmenty hospodárskych vzt’ahov mimoriadneho významu sa vytvárali samostatné organizačné inštitúcie, zatial' čo d’alšie boli podriadené organizačným zložkám už existujúcich ministerstiev alebo iných starších inštitúcií. Nacistické Nemecko pripisovalo vel'ký význam lesnému hospodárstvu, zásobovaniu drevom, drevárskymi polotovarmi a výrobkami. Svedčila o tom skutočnost', že v roku 1934, teda krátko po nástupe nacistov k moci, vznikla samostatná inštitúcia pre uvedené oblasti hospodárstva Ríšsky lesný úrad (Reichsforstamt). Založený bol osobitným Zákonom o prevedení lesného a pol'ovníckeho hospodárstva na Ríšu z júla 1934. Podliehalo mu lesné a drevárske hospodárstvo, polovníctvo, ako aj ochrana prírody a prírodných pamiatok. Na jeho čele stál ríšsky lesný majster (Reichsforstmeister) v pozícii ríšskeho ministra. Túto funkciu zastával až do roka 1945 H. Göring zároveň s postom ríšskeho ministra pre výživu a pol’nohospodárstvo (Reichsministerium für Ernährung und Landwirtschaft). Aktivity H. Göringa však boli skôr zamerané na pol'ovníctvo v d’alšej pozícii ríšskeho pol'ovníckeho majstra (Reichsjägermeister). Lesný úrad v skutočnosti viedol generálny lesný majster (Generalreichsforstmeister). Na danom poste sa do konca vojny vystriedali traja lesní odborníci. Roku 1936 sa Ríšsky lesný úrad rozdelil do šiestich a v roku 1941 až do deviatich odborov. Zároveň prevzal aj riadenie súkromných lesov. Vo vzt'ahu k Slovensku bolo dôležité Oddelenie III pre politiku lesného a drevárskeho hospodárstva (Forst-und Holzwirtschaftspolitikabteilung III), ktoré viedol lesný odborník Willi Parchmann. Uvedené oddelenie a osobne W. Parchmann totiž zastupovali Ríšsky lesný úrad na hospodárskych rokovaniach s krajinami strednej Európy a osobitne so Slovenskom. Po reforme Lesného úradu v roku 1941 sa Parchmannovo pracovisko zmenilo na Oddelenie F pre lesnú politiku a lesnú vedu (Abteilung Forstpolitik und Forstwissenschaft F). ${ }^{5}$

Medzi blízkych spolupracovníkov Ríšskeho lesného úradu patril mladý odborník na lesné a drevárske hospodárstvo vo funkcii hlavného lesného majstra (Oberforstmeister) Dr. Johann Albrecht von Monroy, ktorý absolvoval stáže v USA aj v Sovietskom zväze a prednášal odbor lesného surovinového hospodárstva a drevárskeho priemyslu na Technickej univerzite v Berlíne. Tento v roku 1939 opustil štátnu službu a stal sa koordinátorom prieniku nemeckého kapitálu do drevárskeho priemyslu strednej a juhovýchodnej Európy. Od jesene 1939 rozvíjal bohaté aktivity v danom smere aj na Slovensku. Organizačné funkcie Ríšskeho lesného úradu boli úzko prepojené s príslušnými zložkami Ríšskeho ministerstva hospodárstva (Reichswirtschaftsministerium), predovšetkým

programu budovania ropného hospodárstva z 1. 1. 1939.

5 K vývoju Ríšskeho lesného úradu a jeho štruktúry pozri bližie: RUBNER, Heinrich. Deutsche Forstgeschichte 1933-1945: Forstwirtschaft, Jagd und Umwelt im NS-Staat. St. Katharinen: Scripta Mercaturae Verlag,1997. ISBN 9783895900327. 
so Sekciou les a drevo (Reichsstelle Forst und Holz). Kl'účovou postavou tohto riadiaceho pracoviska bol ministerský radca Dr. Wilhelm Wrabec, ktorý zároveň figuroval aj ako zástupca Ríšskeho lesného úradu. Wrabec už od jarných mesiacov roka 1939 vystupoval na slovensko-nemeckých rokovaniach ako predstavitel' ríšskeho lesného a drevárskeho hospodárstva. ${ }^{6}$

S postupným rozširovaním hospodársko-politického vplyvu Nemecka, respektíve Nemeckej ríše vznikali d’alšie inštitúcie s ciel'om usmerňovat' vývoj lesného a drevárskeho hospodárstve v celej strednej a juhovýchodnej Európe, ako aj v širších celosvetových globálnych rozmeroch. Predmetnú úlohu mal plnit' Ríšsky ústav pre zahraničné a koloniálne lesné hospodárstvo (Reichsintitut für ausländische und koloniale Forstwirtsschaft), založený v roku 1938 v Reinbeku pri Hamburgu. Do zorného uhla nadnárodných plánov novej inštitúcie sa čoskoro dostalo aj Slovensko a na jej pôde, konkrétne v Oddelení svetového lesného hospodárstva (Abteilung für Weltforstwirtschaft) na čele s vedúcim Dr. Wernerom Junghansom, vznikol program využitia lesného bohatstva Slovenska pre systematickú t’ažbu a spracovanie dreva v prospech hospodárskych a vojenských potrieb Nemeckej ríšs. ${ }^{7}$

Záujem vládnych hospodárskych kruhov Nemecka, reprezentovaných vy̌̌šie uvedenými inštitúciami a úradmi o lesné hospodárstvo a drevársky priemysel na území Slovenska sa zvýšil na jeseň 1938 po vyhlásení autonómie a odstúpení južných území Mad’arsku. Strata menej zalesnených južných regiónov znamenala podstatné zvýšenie podielu lesov na celkovej rozlohe Slovenska. Podiel vzrástol z 34,05 \% na 38,33 \%, čím sa územne oklieštené Slovensko po úplnom osamostatnení v marci 1939 stalo tretím najlesnatejším štátom Európy po Švédsku a Fínsku. Celkový objem t’ažby dosahoval okolo 5 mil. $\mathrm{m}^{3}$ dreva ročne. $\mathrm{Na}$ úžitkové drevo pripadalo asi 3 mil. $\mathrm{m}^{3}$, z čoho v období kulminácie hospodárskeho rozvoja samostatného Slovenska približne 1,4 mil. $\mathrm{m}^{3}$ smerovalo k odberatel'om mimo Slovenska. Predstavitelia Nemecka zaradili problematiku drevárstva ako jednu z kl'účových otázok do obsahu slovensko-nemeckých hospodárskych rokovaní, ktoré začali už v prechodnom období existencie druhej ČS-R a pokračovali s rastúcou intenzitou v podmienkach nového Slovenského štátu. ${ }^{8}$ Na slovenskej strane postupne vznikali centrálne orgány, inštitúcie a kor-

6 Politisches Archiv des Auswärtigen Amtes Berlin (d’alej PA AA), f. Gesandtschaft Preßburg (d’alej GP), kartón (d’alej k.) 207, Plán príchodu nemeckých odborníkov na Slovensko, predložený na prvom zasadnutí slovensko-nemeckých vládnych výborov 25. 4. 1939.

7 Slovenský národný archív (d’alej SNA), f. Ministerstvo hospodárstva 1938 - 1945 (d’alej $\mathrm{MH}$ ), inv. č. 27, k. 49. Stanovisko Ústredného riaditel'stva štátnych lesov a pozemkov z 30. 10. $1940 \mathrm{k}$ programu slovensko-nemeckej spolupráce $\mathrm{v}$ lesnom a drevárskom hospodárstve od prezidenta Ríšsko-nemeckého drevárskeho syndikátu F. Hamburgera.

8 BArch Berlín, f. R 3701, zv. 403. Základné údaje o t’ažbe, spracovaní a vývoze dreva, uvádzané k návrhu na reorganizáciu slovenského drevárstva z 30. 3. 1943. 
porácie pre oblast' lesného hospodárstva a drevárskeho priemyslu vstupujúce do kontaktu s nemeckými partnermi daného segmentu hospodárstva. Riadenie celej sféry lesníctva a drevárstva prevzalo už v období autonómie samostatné ministerstvo hospodárstva. Nové ministerstvo zriadilo v apríli 1939 Výbor pre vývoz dreva, pozostávajúci z predstavitel’ov viacerých štátnych úradov a súkromných organizácí́.

Na konci mája 1939 vznikol poradný zbor ministerstva hospodárstva Drevárska rada, pretvorená vládnym nariadením č. 121 z 20. júla 1939 na Lesnícku a drevársku radu. V jej rámci figurovali zástupcovia lesnej prvovýroby, piliarstva a drevárskeho obchodu, reprezentovaní Združením majitel'ov lesov na Slovensku, Zväzom drevárskeho hospodárstva a lesno-drevárskou sekciou Ústredného združenia slovenského priemyslu. Lesy a spracovatel'ské závody v rukách štátu podliehali Ústrednému riaditel'stvu štátnych lesov a majetkov. Samostatne pôsobila družstevná korporácia Zväz slovenských výrobcov a dodávatel'ov pražcov, družstvo s.r.o., s výhradnou právomocou exportovat' železničné podvaly a vývozný podnik Dredoma, zameraný osobitne na drevárske obchody s Mad’arskom. ${ }^{9}$

Kapitáni nemeckého hospodárstva začali Slovensko preukázatel'ne vnímat' ako samostatný, respektíve doplnkový, hospodársky priestor po vyhlásení autonómie 6. októbra 1938. Dôkazom bol obsah rozhovorov zmocnenca pre štvorročný plán $\mathrm{H}$. Göringa s predstavitel'mi radikálneho krídla nového vládneho režimu autonómneho Slovenska Alexandrom Machom a Ferdinandom Ďurčanským 12. októbra 1938 v Göringovom sídle Karinhall pri Berlíne. Göring ponúkol slovenským radikálom okrem iného aj hospodársku spoluprácu a oboznámil ich so zámerom Nemecka zapojit' Slovensko do štvorročného hospodárskeho plánu. V nasledujúcich mesiacoch sa konalo viacero stretnutí nemeckých a slovenských národohospodárov. Osobitné aktivity v hospodárskych stykoch prejavoval štátny sektár W. Keppler, najmä v oblasti prieskumu ropných ložísk a zásob nerastných surovín.

Slovensko-nemecké hospodárske styky pred zánikom ČSR vyvrcholili návštevou skupiny slovenských národohospodárov na čele $\mathrm{s}$ ministrom hospodárstva Mikulášom Pružinským v Berlíne 1. - 3. marca 1939 na pozvanie H. Göringa. Spoločné rokovania dohodol najbližší spojenec nacistického Nemecka v slovenskej vládnej garnitúre Vojtech Tuka počas návštevy v Berlíne v polovici februára 1939. Zástupcovia slovenského hospodárskeho života vrátane exponentov medzivojnového režimu ako bol Peter Zat'ko hl'adali na nemeckej strane pomoc a východisko zo zložitej ekonomickej situácie autonómneho Slovenska. Predstavili možnosti hospodárskej spolupráce a ponúkli dodávky

9 LÁNGOŠ, ref. 1, s. 17-18. 
tovarov, ktoré mali pre Nemecko strategický význam. Išlo predovšetkým o potraviny, ropu a drevo. Göring potvrdil záujem Nemecka o rozvoj hospodárskych stykov a prislúbil ekonomickú pomoc, ktorú však podmienil úplným osamostatnením Slovenska. ${ }^{10}$

Po rozpade ČSR a vzniku samostatného Slovenského štátu sa základom slovensko-nemeckých hospodárskych vzt’ahov stal Tajný protokol o hospodárskej a finančnej spolupráci, ktorý bol dodatkom Zmluvy o ochrannom pomere medzi Slovenským štátom a Nemeckou ríšou z 23. marca 1939. Tajný protokol kodifikoval vazalský hospodársky vzt’ah Slovenska k Nemecku, ale zároveň poskytoval možnosti technologickej a finančnej pomoci zo strany nemeckých hospodárskych kruhov. Slovensku určoval úlohu dodávatel'a surovín a poskytovatel’a dopravnej infraštruktúry pre potreby Nemeckej ríše. Podl'a prvého článku Tajného protokolu mal Slovenský štát $\mathrm{v}$ prospech hospodárskych potrieb Nemecka rozvíjat' v prvom rade pol'nohospodárstvo a produkciu potravín a hned' na druhom mieste drevárstvo a lesný priemysel na základe dlhodobých ciel'avedomých plánov. Na tret'om mieste bolo vyhl'adávanie a dodávky nerastných surovín. Pre d’alší vývoj obchodu s drevom a jeho exportu mimo územia Slovenska mal d’alekosiahly význam jeden z bodov tretieho článku Tajného protokolu, podl'a ktorého mohla slovenská vláda viest’ hospodárske rokovania s tretími krajinami až po uzavretí dohôd s Nemeckom a s jeho vedomím. ${ }^{11}$

V apríli až máji 1939 sa v Bratislave, Prahe a v Berlíne konali zložité rokovania slovenských a nemeckých hospodárskych predstavitel'ov s ciel'om konkretizovat' všeobecné ustanovenia Tajného protokolu na jednotlivé segmenty hospodárstva a vypracovat' pre ne výhl'adové plány. Dôležitou súčast'ou rokovaní boli aj otázky rozvoja lesného hospodárstva a drevárskeho priemyslu. Koncom apríla 1939 navštívila Bratislavu delegácia Ríšskeho ministerstva hospodárstva, aby dohodla program reprezentatívneho stretnutia zástupcov slovenských a nemeckých hospodárskych orgánov, inštitúcií a korporácií, plánovaného na druhú polovicu mája 1939. Z iniciatívy nemeckej delegácie boli vytvorené tri hospodárske skupiny odborníkov: priemyselná, pol’nohospodárska a lesno-hospodárska, ktoré mali osobitne zostavovat' plány spolupráce v jednotlivých sférach ekonomiky.

10 K formovaniu slovensko-nemeckých hospodárskych vzt'ahov na prelome rokov 1938/1939 pozri bližšie: HALLON, L’udovít. Zmeny orientácie hospodárskej politiky na Slovensku 1938 - 1939 a vznik Slovenského štátu. In BYSTRICKÝ, Valerián - MICHELA, Miroslav - SCHVARC, Michal (eds.). Rozbitie alebo rozpad? Historické reflexie zániku Česko-Slovenska. Bratislava: Veda, 2010, s. 174-190. ISBN 9788022411509.

11 Akten zur deutschen auswärtigen Politik (d’alej ADAP), séria D, IV. zväzok, dok. č. 40. Tajný protokol o hospodárskej a finančnej spolupráci medzi Nemeckou ríšou a štátom Slovensko z 23. 3. 1939; PA AA, f. GP, k. č. 207, Plán príchodu nemeckých odborníkov na Slovensko, predložený na prvom zasadnutí slovensko-nemeckých vládnych výborov 25. 4. 1939. 
Vznikli podl'a vzoru hospodárskych skupín Ríšskeho ministerstva hospodárstva. V rámci návštevy nemeckej delegácie sa zároveň kreovali slovensko-nemecké vládne výbory pre hospodárske otázky pozostávajúce z národohospodárov oboch strán. Tieto pravidelne zasadali a riešili kl'účové hospodárske otázky počas celej existencie Slovenskej republiky 1939 - 1945. Na čele nemeckého výboru stál vo funkcii predsedu ministerský radca Günther Bergemann a predsedom slovenského vládneho výboru bol minister bez kresla a predstavitel' slovenskej hospodárskej diplomacie Dr. Štefan Polyák. ${ }^{12}$ Dňa 22. apríla 1939 vládne výbory usporiadali svoje zatial' iba nulté zasadnutie. Hlavný obsah rokovaní tvorila príprava obchodnej zmluvy a plány tovarovej výmeny vrátane dodávok dreva. Dôležitým záverom rozhovorov bol aj dokument z 25. apríla 1939 o vyslaní nemeckých odborníkov z rôznych oblastí hospodárstva do nového Slovenského štátu. Mali sa podiel'at' na koncipovaní slovensko-nemeckých rozvojových programov. Nemecký vládny výbor prislúbil aj vyslanie odborníka na oblast' drevárstva W. Wrabca ako zástupcu Ríšskeho ministerstva hospodárstva a zároveň Ríšskeho lesného úradu. Po príchode na Slovensko začiatkom mája 1939 sa mal zaoberat' technickou modernizáciou lesného hospodárstva a rozširovaním kapacít drevárskeho priemyslu. ${ }^{13}$

Plánované rokovania strategického významu za účasti popredných zástupcov viacerých odvetví nemeckého a slovenského hospodárstva sa konali v Bratislave 23. - 25. mája 1939. Na Slovensko prišli významní predstavitelia Ríšskej skupiny pre priemysel (Reichsgruppe Industrie) a Ríšskeho ministerstva hospodárstva. Medzi členmi reprezentatívnej delegácie figurovali exponenti viacerých nemeckých firiem a korporácií. Záujmy priemyslu spracovania dreva presadzoval napríklad spolumajitel' rakúskej drevárskej firmy Brüder Hasslacher and Co . a jeden z členov predstavenstva Oblastnej skupiny Sudety Hospodárskej skupiny pre papier, celulózu a drevárstvo v Liberci. Slovenskú delegáciu viedli najvyšší hospodárski predstavitelia minister financií M. Pružinský, minister hospodárstva Gejza Medrický, guvernér Slovenskej národnej banky Imrich Karvaš, tajomník Ústredného zväzu slovenského priemyslu P. Zat'ko, člen vedenia Bratislavskej obchodnej a priemyselnej komory Ján Liška a d’alší. Na program hospodárskych rokovaní sa dostalo celé spektrum aktuálnych otázok, ale hlavnou témou mali byt' rozvojového projekty slovenského priemyslu za účasti nemeckého kapitálu

12 V nasledujúcich rokoch sa na čele nemeckého vládneho výboru vystriedali tiež odborník na hospodárstvo krajín strednej Európy a legačný radca Obchodno-politického oddelenia Zahraničného úradu (Handelspolitische Abteilung des Auswärtigen Amtes) Dr. Karl Hudeczek a Karl-Gisbert Schultze-Schlutius.

13 PA AA, f. GP, k. 207. Tajný záznam o slovensko-nemeckých rokovaniach v Bratislave 21. a 22. 4. 1939; PA AA, f. GP, k. č. 207, Plán príchodu nemeckých odborníkov na Slovensko, predložený na prvom zasadnutí slovensko-nemeckých vládnych výborov 25. 4. 1939. 
a nemeckej technologickej pomoci. Medzi odvetvia s najhlbšie rozpracovanými plánmi rozvoja sa zaradilo práve lesné hospodárstvo a drevársky priemysel. Pozitívnym faktorom bola skutočnost', že vládne hospodárske kruhy Nemecka okrem dovozu gul'atiny dávali značný dôraz aj na dodávky drevárskych polotovarov a hotových výrobkov zo slovenských závodov. Plánovali podstatné rozšírenie výrobných kapacít a zásadnú modernizáciu starších piliarskych závodov prostredníctvom dodávok moderných typov píl a d’alších drevospracujúcich strojov od nemeckých firiem. Kapacity d'alšieho spracovania dreva a výroby finálnych produktov plánovali rozšírit' výstavbou štyroch nových závodov na debny, preglejky, drevné melivo a tvrdené drevené platne. Na rozvoj drevárstva malo nadviazat' budovanie nových kapacít $\mathrm{v}$ priemysle celulózy a viskózových vlákien, konkrétne výstavbou závodu na viskózovú vlnu v spolupráci s firmou Bat’a a na viskózové vlákna v súčinnosti s bratislavským podnikom Dynamit Nobel, respektíve s chemických koncernom I. G. Farbenindustrie. Do úvahy prichádzali aj závody na tvrdenú lepenku, drevené uhlie, drevný lieh a drevný cukor. $^{14}$

Hlavné zásady slovensko-nemeckého obchodu s drevom a výrobkami drevárskeho priemyslu sa stali obsahom prvého oficiálneho zasadnutia slovensko-nemeckých vládnych výborov 9. - 22. júna 1939 v Bratislave. Zasadnutie vyvrcholilo podpísaním obchodnej zmluvy medzi Nemeckou ríšou a Slovenským štátom (Handelsvertrag). Vládne výbory zároveň rozpracovali plány modernizácie lesného hospodárstva a t’ažby dreva. Nemeckí národohospodári prisl'úbili dodávky techniky na približovanie dreva, ako zariadenia na výstavbu lanových dráh, lesných železníc a ciest, traktory, rôzne t’ahače a vozíky na dopravu dreva. Na d’alšie spracovanie drevnej hmoty mali byt' dovezené ručné a motorové píly, motorové frézy, sekery, potreby na budovanie lesných škôlok. Budúci vývoj drevárstva plánovali postavit' na vedecké základy za pomoci nemeckých odborníkov. Nové poznatky mali šírit' vzorové lesné a drevárske podniky, zriadené v rôznych častiach Slovenska. Ohl'adne obchodu s drevom základnou podmienkou mali byt' pevne stanovené kontingenty dodávok surového dreva a pevné ceny jednotlivých drevárskych produktov, aby sa eliminovali negatívne dopady výkyvov na trhu. Ceny mohli byt' upravené len po zásadnej zmene hospodárskeho vývoja. Táto dohoda sa čoskoro ukázala ako nevýhodná pre Slovensko, lebo výrobné náklady v odvetví rýchlo rástli a výrobcovia mohli do ceny premietnut' zvyšovanie dopytu po dreve na domácom a medzinárodnom trhu až po určitom čase. V rámci systému vládnych výborov postupne vznikala siet' podvýborov a komisií pre jednotlivé oblasti hospodárstva. Jedným z prvých komponentov tejto siete bol osobitný Nemecký výbor pre lesné a drevárske hospodárstvo Slo-

14 BArch Berlín, f. R 70 Slowakei, zv. 332. Slovensko-nemecké rokovania 23. - 25. 5. 1939. 
vensko (Deutsche Forst und holzwirtschaftliche Ausschuss für Slowakei), ktorý mal riešit' problematiku t'ažby, spracovania a obchodu s drevom. Tento podliehal Ríšskemu lesnému úradu a plnil jeho inštrukcie. Dokladom bola skutočnost', že na čele výboru stál exponent Ríšskeho lesného úradu W. Wrabec. Pendantom nemeckého výboru na rokovaniach o drevárskej problematike sa stala Slovenská lesná a drevárska rada, vedená národohospodárom P. Zat'kom. ${ }^{15}$

Ďalší vývoj slovensko-nemeckej spolupráce v oblasti lesného a drevárskeho hospodárstva sa uberal dvomi hlavnými smermi. Prvým bol obchod s rôznymi druhmi drevárskych produktov, respektíve vývoz dreva do Nemeckej ríše a druhým spolupráca na rozvoji slovenského drevárskeho priemyslu za účasti nemeckého kapitálu. Vytvorením samostatného ekonomického priestoru Slovenského štátu význam drevárstva $\mathrm{v}$ hospodárstve Slovenska a najmä v štruktúre jeho vývozu podstatne vzrástol. Exportnou cudzinou sa stal aj najväčší odberatel' slovenského dreva české krajiny. Úlohu najväčšieho odberatel'a plnili aj po strate Sudet a vytvorení Protektorátu Čechy a Morava. Treba však zdôraznit', že na základe slovensko-nemeckých hospodárskych dohôd ostala medzi novou Slovenskou republikou a Protektorátom zachovaná colná únia. Vojnová konjunktúra na medzinárodných trhoch, ako aj v domácom hospodárstve Slovenska motivovala rast t’ažby dreva a tiež jeho spracovanie na piliarske polotovary a hotové výrobky. V zahraničnom obchode medzivojnovej ČSR dosahovalo drevárstvo podiel len okolo $4 \%$, zatial' čo v exporte samostatného Slovenska vzrástol podiel dreva už počas roka 1939 v hodnotovom vyjadrení na $20,6 \%$. V nasledujúcich rokoch 1940 - 1943 sa podiel nad'alej pohyboval okolo $20 \%$ s výnimkou roka 1942, ked' vzhl’adom na nižšiu celkovú hodnotu exportu vzrástol až na $29 \%{ }^{16}$

Nemecko vstúpilo do drevárskych obchodov Slovenského štátu v roku 1939 už ako Nemecká ríša spolu s územím dnešného Rakúska, čiže Ostmarky a s územím českých Sudet. Po zrušení colnej hranice medzi Nemeckom a Protektorátom v októbri 1940 sa v rámci zahraničného obchodu Nemeckej ríše spravidla vykazovalo aj územie Protektorátu. Na zúčtovanie drevárskych, ako aj d’alších

15 PAAA, f. GP, k. 207. Tajný protokol z prvého zasadnutia slovenského a nemeckého vládneho výboru 9. - 22. 6. 1939 v Bratislave; pozri tiež PA AA, f. R 111 306, zv. 1; Obchodná zmluva medzi Slovenskou republikou a Nemeckou ríšou z 22. 6. 1939. In Slovenský zákonník, 1942, č. 6, čiastka 4, s. 179- 267.

16 Drevársky priemysel. In Slovenský priemysel. Výročná správa Združenia slovenského priemyslu (d’alej Slovenský priemysel), 1939, s. 20; Drevársky priemysel. In Slovenský priemysel, 1940, s. 18-19; Drevársky priemysel. In Slovenský priemysel, 1941, s. 16; Drevársky priemysel In Slovenský priemysel, 1942, s. 19; Drevársky priemysel. In Slovenský priemysel, 1943, s. 20; BArch Berlín, f. R 3701, zv. 396. Správa predsedu slovenského vládneho výboru Š. Poljáka predsedovi nemeckého vládneho výboru G. Bergemannovi z 19. 3.1942 o štruktúre slovenského vývozu do Nemeckej ríše a o podiele jednotlivých druhov tovaru na exporte do Ríše v roku 1941. 
obchodov medzi Slovenským štátom, neskôr Slovenskou republikou a Nemeckou ríšou slúžili clearingové účty $\mathrm{v}$ rámci bezhotovostného styku a ústredná Nemecká zúčtovacia pokladňa (Deutsche Verrechnungskasse). Od roka 1940 prebiehali cez Nemeckú zúčtovaciu pokladňu aj obchody s Protektorátom a následne tiež $\mathrm{s}$ územiami, ktoré boli vojensky anektované Nemeckom. $\mathrm{V}$ rámci systému clearingových účtov umožňujúcich bezhotovostné zúčtovanie tovarových obchodov a platieb sa využíval na obchod s drevom najmä Tovarový účet (Warenkonto). Na obchodný styk s Protektorátom slúžil predovšetkým Kapitálový účet (Kapitalkonto) a obchod s anektovanými krajinami sprostredkoval Účet obsadené územia (Besetzte Gebietekonto). ${ }^{17}$

Podl'a obsahu slovensko-nemeckých rokovaní z jarných mesiacov roka 1939 a v zmysle obchodnej zmluvy z 22. júna 1939 sa drevárske obchody vyvíjali na základe vopred stanovených kontingentov a cien. Tieto boli dohodnuté na spoločných zasadaniach Nemeckého výboru pre lesné a drevárske hospodárstvo a Slovenskej lesnej a drevárskej rady. Nemeckú stranu na zasadnutiach okrem ministerského radcu W. Wrabca zastupoval d’alší exponent Ríšskeho lesného úradu W. Parchmann, ako aj predstavitelia viacerých drevárskych inštitúcií, korporácií a firiem. Slovensko zastupovali okrem P. Zat'ka generálny riaditel' Ústredného riaditel'stva štátnych lesov a majetkov Ing. Jozef Biringer, generálny tajomník Drevárskeho zväzu Dr. Ján Kempný, zástupca ministerstva hospodárstva a lesný radca Štátnych lesov a majetkov Ing. Koloman Kosljar, viceguvernér národnej banky Dr. Jozef Fundárek, minister hospodárstva G. Medrický a iní. Nemecký výbor sa vnútorne rozčlenil na dve osobitné komisie pre ihličnaté a listnaté drevo. Slovenská lesná a drevárska rada však pôsobila len do jesene 1941. Na pozadí formovania vojnového hospodárstva dochádzalo $\mathrm{k}$ prehlbovaniu štátno-monopolistického usmerňovania ekonomiky vrátane lesného a drevárskeho hospodárstva. V danej súvislosti vláda poverila ministerstvo hospodárstva rozšírenými kompetenciami, ktoré minister G. Medrický vyhláškou č. 245/1941 preniesol na nový orgán Lesnú a drevársku ústredňu. Táto prevzala aj právomoci Slovenskej lesnej a drevárskej rady, ktorá následne zanikla. Nová ústredňa vstúpila do slovensko-nemeckých rokovaní, ale intenzívne rozhovory si vyžiadali kreovanie d’alšieho osobitného orgánu Slovenského výboru pre lesné a drevárske hospodárstvo v pozícii nového „zrkadlového“ pendanta Nemeckého výboru pre lesné a drevárske hospodárstvo. ${ }^{18}$

17 K vývoju clearingového zúčtovania pozri: PA AA, f. R 105 327. Správa o vývoji slovensko-nemeckého platobného styku z 18. 1. 1943; Bundesarchiv - Militärarchiv (d'alej BA - MA) Freiburg, f. RW 29/4a. Situačné správy Deutsche Industriekommission Slowakei z 11. 10. 1943, 10. 1. 1944, 10. 6. 1944, 10. 8. 1944.

18 PA AA, f. GP, k. 207. Dohoda Slovenskej lesnej a drevárskej rady a Nemeckého výboru pre lesné a drevárske hospodárstvo o organizácii a zabezpečení pravidelného chodu tovarovej 
V oblasti drevárstva, ako aj v d’alších sférach hospodárstva už od jari 1939 pôsobili viacerí nemeckí odborníci. Napriek tomu sa z iniciatívy nemeckého vyslanca na Slovensku Hansa Bernarda a hlavného predstavitel'a nemeckej menšiny na Slovensku Franza Karmasina začali vysielat' na Slovensko nemeckí poradcovia tzv. beráteri pre jednotlivé segmenty hospodárstva, podobne ako aj pre ostatné sféry života spoločnosti. Vysielanie poradcov urýchlili aktivity H. Bernarda, ktorý sprostredkoval audienciu F. Karmasina priamo u nemeckého ministra zahraničných vecí Joachima von Ribbentropa v decembri 1939. Do slovenského hospodárstva následne prichádzali beráteri obchodný atašé, neskôr poradca pri ministerstve hospodárstva Dr. Erich Gebert, poradca pre pol'nohospodárstvo Dr. Hans Hamscha a osobitný poradca pre lesné a drevárske hospodárstvo Dr. Franz Wechselberger.

V rámci ich činnosti malo odborné poradenstvo len vedlajšiu funkciu. Hlavnou úlohou bola kontrola prideleného hospodárskeho rezortu, pravidelné hlásenia o jeho vývoji a presadzovanie nemeckých hospodárskych záujmov. ${ }^{19}$ Franz Wechselberger v Nemecku pôsobil ako Oberforstmeister. Plnil inštrukcie Ríšskeho lesného úradu, na ktorého čele stál Reichsforstmeister H. Göring, ako aj príkazy ministerstva hospodárstva a d'alších vládnych hospodárskych inštitúcií Nemeckej ríše. Na pôde Slovenskej republiky vystupoval v pozícii lesného atašé nemeckého vyslanectva. Sprostredkoval slovensko-nemecké rokovania o otázkach drevárstva a tiež styky s nemeckými vládnymi hospodárskymi orgánmi, s nemeckými drevárskymi korporáciami a firmami.

Ministerstvo hospodárstva privítalo nástup lesného atašé v liste na nemecké vyslanectvo $\mathrm{v}$ Bratislave $\mathrm{z}$ januára 1940. K úlohe $\mathrm{F}$. Wechselbergera sa ministerstvo vyjadrilo nasledovne: „Lesný attaché môže vládu Slovenskej republiky priamo informovat' o aktuálnych lesných a drevárskych otázkach v Nemecku, prispievat' $k$ prispôsobeniu lesného a drevárskeho hospodárstva v Slovenskej republike pomerom $v$ Nemecku, a takto usnadňovat' tiež činnost' odboru IX. ministerstva hospodárstva... "20 Prednosta IX. odboru v liste navrhoval, aby sa zriadila aj pozícia slovenského lesného atašé pri vyslanectve Slovenskej republiky v Berlíne. Na túto pozíciu odporúčal dosadit' generálneho riaditel’a štátnych lesov a majetkov Ing. Jozefa Biringera.

výmeny v lesnom hospodárstve z 11. 9. 1940 v Trenčianskych Tepliciach; PA AA, f. GP, k. 210. Zasadanie Slovenského lesného a drevárskeho výboru a Nemeckého výboru pre lesné a drevárske hospodárstvo 21. - 24. 9. 1942 v Bratislave; Drevársky priemysel. In Slovenský priemysel, 1941, s. 18.

19 ADAP, séria D, VIII. zväzok, dokument č. 409. Záznam štátneho sekretára E. Woermanna o prijatí F. Karmasina u ministra zahraničia J. v. Ribbentropa 1. 12. 1939; K systému beráterov pozri bližšie: SUŠKO, Ladislav. Systém beráterov v nacistickom ovládaní Slovenska v rokoch 1939 - 1945. In Historické štúdie, 1979, roč. 23, s. 5-23.

20 SNA, f. MH, inv. č. 27, k. 43. List Ministerstva hospodárstva Slovenskej republiky na nemecké vyslanectvo v Bratislave z 5. 1. 1940. 
Predmetom slovensko-nemeckých drevárskych obchodov bola rozsiahla škála tovarov od suroviny cez polotovary až po hotové výrobky. Slovensko dodávalo ihličnatú a listnatú gul'atinu $\mathrm{v}$ rôznych dížkach, priemeroch a triedach kvality, mokré a sušené, desiatky druhov piliarskych polotovarov, banské drevo, stavebné drevo, podvaly, celulózové drevo, generátorové drevo na výrobu plynu, štiepku, piliny a melivo, palivové drevo, kôru, milierové drevené uhlie, impregnované telegrafné a telefónne stípy, debny, parkety, nábytok, neskôr aj preglejky a viacvrstevné tvrdené dosky pre letecký priemysel, drevené komponenty pre automobily a iné dopravné prostriedky, kompletné montované baraky a domy. Drevárske obchody zahŕňali aj chemicky spracované drevo vo forme celulózy, drevného liehu a dreveného uhlia vyrábaného suchou destiláciou dreva alebo drevného cukru. Nemeckí odberatelia boli pritom vel'mi nároční. Vyžadovali presné dodržovanie rozmerov a kvality jednotlivých drevárskych produktov, od čoho sa odvíjala cena. Hlavný podiel na exporte drevárskej produkcie, najmä gul'atiny a polotovarov, do Nemeckej ríše a d'alších krajín malo ihličnaté drevo, ktoré zároveň dosahovalo približne o tretinu vyššie ceny než listnaté drevo. Roku 1939 dosiahol podiel ihličnatého dreva na celkovom objeme vývozu slovenského drevárstva približne $70 \%{ }^{21} \mathrm{~S}$ prehlbovaním vojnových potrieb sa však ihličnaté drevo stávalo na medzinárodnom aj domácom trhu nedostatkovou komoditou, preto jeho t'ažbu a odbyt postupne obmedzovali štátno-monopolistické opatrenia. Zároveň rástol význam a ceny listnatého dreva, najmä bukového, ktoré sa využívalo na výrobu strategicky dôležitých tovarov, ako preglejky a tvrdené dosky pre letectvo. Úzkym profilom drevárskych obchodov sa už od roka 1939 stalo celulózové drevo, žiadané v Nemeckej ríši, na medzinárodných trhoch a zároveň existenčne dôležité pre slovenské celulózky. Preto bolo d’alším objektom zásahov a obmedzení trhu zo strany štátu. Problém spočíval aj v oblasti technológií, ked’že na výrobu celulózy bolo možné v sledovaných rokoch využit' len stále menej dostupné ihličnaté drevo. Po kulminácii vojnovej konjunktúry a následnom všeobecnom nedostatku surovín a polotovarov sa problém nedostatočných zdrojov rozšíril na väčšinu produktov sledovaného odvetvia. Išlo najmä o podvaly, drevené uhlie, celulózu a iné tovary. ${ }^{22}$

21 PA AA, f. GP, k. 207. Dohoda Slovenskej lesnej a drevárskej rady a Nemeckého výboru pre lesné a drevárske hospodárstvo z 11. 9. 1940 v Trenčianskych Tepliciach; PA AA, f. GP, k. 207. Príloha F Protokolu z tretieho zasadnutia slovensko-nemeckých vládnych výborov z 23. až 26. 4. 1941 v Bratislave; Drevársky priemysel. In Slovenský priemysel, 1939, s. 19; LACKO, Richard. 100 rokov drevárskej výroby v Turanoch (1887 - 1987). Martin: Tlačiarne SNP, 1987, s. 47.

22 SNA, f. Úrad predsedníctva vlády 1939 - 1945 (d’alej ÚPV 1939 - 1945), inv. č. 66, k. 89. Memorandum slovenských papierní a celulózok adresované Slovenskej lesnej a drevárskej rade o zásobovaní celulózok drevom a obmedzení exportu celulózového dreva z 5. 9. 1939; Drevársky priemysel. In Slovenský priemysel, 1942, s. 18; PA AA, f. R 105 331. Príloha D Protokolu zo siedmeho zasadnutia slovensko-nemeckých vládnych výborov v septembri až 
Vládne hospodárske kruhy, národohospodári, ako aj predstavitelia lesného hospodárstva a drevospracujúceho priemyslu zaujímali k vývoju slovensko-nemeckých drevárskych obchodov bipolárny postoj. Vítali nárast odbytu, ktorý v predchádzajúcom období 30. rokov znamenal vel'ký problém, ale na druhej strane mali obavy, že rozmach exportu ohrozí zásobovanie domáceho trhu a prijímali ochranné opatrenia. Zároveň sa pokúšali nasmerovat' vývoz drevárskych výrobkov, najmä gul'atiny, polotovarov, dreveného uhlia, celulózy do neutrálnych štátov, kde práve táto čast' exportu bola vel'mi žiadaná a uhrádzaná vol'nými devízami.

Zástupcovia nemeckého hospodárstva na pôde vládnych a drevárskych výborov kriticky hodnotili opatrenia na obmedzenie exportu, ako aj tendencie zvyšovat' vývoz drevárskej produkcie do neutrálnych štátov na úkor Nemecka, ale tlak na zvyšovanie dodávok do priestoru Nemeckej ríše prehlbovali len postupne a zameriavali sa iba na určité komodity aktuálne žiadané na trhoch Ríše. Počiatočný zmierlivý postoj nemeckých národohospodárov v drevárskych obchodoch mal aj d’alšiu málo známu príčinnú súvislost'. Počas rokovaní v apríli 1939 v Bratislave práve nemecká strana navrhla, aby Slovensko získavalo devízy exportom dreva a produktov jeho spracovania. Mala to byt' určitá náhrada, lebo Nemecko zabralo celý zlatý poklad aj devízové rezervy bývalej ČSR a Slovensku poskytlo iba minimálne zdroje devíz. ${ }^{23} \mathrm{Na}$ zvyšovaní exportu a celkovej produkcie v sledovanom odvetví mali okrem Nemecka a d’alších odberatel'ov vel'ký záujem aj samotní dodávatelia dreva a výrobcovia drevárskeho tovaru. Boli motivovaní rastom dopytu, cien a ziskov, ktoré v obchode s Nemeckou ríšou deformoval nereálne vysoký kurz nemeckej marky voči slovenskej korune. Štátno-monopolistické opatrenia na reguláciu trhu a stabilizáciu cien boli preto zamerané aj na usmerňovanie aktivít výrobnej základne drevárstva.

Nemecká ríša spolu s územím Protektorátu Čechy a Morava dosahovala počas rokov 1939 - 1943, z ktorých máme k dispozícii údaje, hlavný podiel na drevárskom vývoze Slovenska. Spoločný podiel sa na základe správ Ústredného združenia slovenského priemyslu pohyboval asi od $67 \%$ do 84 \%. Najväčším odberatel'om však bolo samotné územie Protektorátu, závislé na dodávkach slovenského dreva s podielom približne $44 \%$ až $53 \%$. Nemecko, respektíve Nemecká ríša s dnešným Rakúskom (Ostmarkou) a Sudetami, dosahovala až druhý najväčší podiel v rozmedzí asi $24 \%$ až 27 \%. Presnejšie údaje o vývoze máme z rokov 1939 - 1941, zatial' čo z obdobia rokov 1941 - 1943 sú známe len celko-

októbri 1943; PA AA, f. R 105 331. Príloha O Protokolu z ôsmeho zasadnutia slovensko-nemeckých vládnych výborov v apríli až júni 1944.

23 PA AA, f. GP, k. 207. Tajný záznam zo slovensko-nemeckých rokovaní v Bratislave 21. až 22. 4. 1939; PA AA, f. GP, k. 207. Protokol z nultého zasadnutia slovensko-nemeckých vládnych výborov 22. 4. 1939. 
vé objemy exportu do Nemeckej ríše spolu s Protektorátom a údaje pre jednotlivé územia sú približné alebo odhadované. V hodnotovom vyjadrení sa celkový export gul'atiny a drevárskych výrobkov zvýšil v rokoch 1939- 1943 zo 476 mil. Ks na 1079 mil. Ks. Uvedený rast však bol najmä výsledkom postupu inflácie a zvyšovania cien dreva. V objemových ukazovatel'och export zaznamenal rast iba v rokoch 1939 - 1940 z 1087 tis. t. na 1324 tis. t. V d’alších rokoch vývoz postupne klesal až na 939 tis. t. v roku 1943. V prípade Nemeckej ríše a Protektorátu sa znižoval aj podiel na exporte, takže v objemových ukazovatel'och klesli dodávky drevárskych tovarov do Nemeckej ríše v rokoch 1940 - 1943 z 354 tis t približne na 225 tis. $t$ a do Protektorátu z 581 tis. $t$ asi na 405 tis. t. ${ }^{24}$

Pozícia Ríše v drevárskych obchodoch so Slovenskom bola okrem iného ovplyvnená aj konkurenciou d'alších štátov, najmä tých, ktoré poskytovali výhodnejšie ceny a devízy. Medzi tradičných odberatel'ov slovenského dreva patrilo Mad'arsko, ale jeho význam v porovnaní s medzivojnovým obdobím výrazne klesol. $\mathrm{V}$ exporte figurovalo na tret'om až štvrtom mieste $\mathrm{s}$ maximálnym podielom $13 \%$ v roku 1940. Obchody však realizovalo formou clearingu podobne ako Ríša a v kompenzačnej výmene tovaru bolo pasívne, lebo nedokázalo ponúknut' za vyvezené drevo náležitú náhradu. Po rozšírení územia v roku 1940 získalo nové vlastné zdroje dreva.

Pre slovenský vývozcov bolo zaujímavejšie Holandsko, aj ked' len do polovice roka 1940, d’alej nový spojenec Taliansko a lukratívny odberatel' Švajčiarsko. Holandsko najmä v dôsledku hospodárskej blokády na začiatku roka 1940 zvýšilo podiel na exporte slovenského drevárstva počas rokov 1939 - 1940 zo $6,6 \%$ na $8,4 \%$. Po obsadení Nemeckom však začalo spolu s d’alšími obsadenými územiami realizovat' obchod prostredníctvom Nemeckej zúčtovacej pokladne. Nebezpečným konkurentom Nemeckej ríše v drevárskych obchodoch so Slovenskom sa stalo fašistické Taliansko, ktoré poskytovalo výhodnejšie ceny. V rokoch 1939 - 1942 zvýšilo podiel na slovenskom exporte z 0,2 \% na 18,5 \%. Jeho pozíciu oslabili až zmeny na vojnových frontoch v lete 1943. Priaznivo sa vyvíjali drevárske obchody so Švajčiarskom, realizované prostredníctvom devíz. V rokoch 1939 - 1943 ich podiel vzrástol z $0,12 \%$ na $6 \%{ }^{25}$

24 Drevársky priemysel. In Slovenský priemysel, 1939, s. 19-20; Drevársky priemysel. In Slovenský priemysel, 1940, s. 17-19; Drevársky priemysel. In Slovenský priemysel, 1941, s. 16; Drevársky priemysel. In Slovenský priemysel, 1942, s. 19-20; Drevársky priemysel. In Slovenský priemysel, 1943, s. 20; LÁNGOŠ, ref. 1, s. 18-20.

25 Drevársky priemysel. In Slovenský priemysel, 1939, s. 19-20; Drevársky priemysel. In Slovenský priemysel, 1940, s. 19; Drevársky priemysel. In Slovenský priemysel, 1941, s. 16-17; Drevársky priemysel. In Slovenský priemysel, 1942, s. 20; Drevársky priemysel. In Slovenský priemysel, 1942, s. 20-21; BArch Berlín, f. R 3701, zv. 399. Správa Ríšskeho lesného úradu na Zahraničný úrad v Berlíne z 31. 5. 1943 o vývoji cien dreva na slovensko-nemeckom a slovensko-talianskom trhu. 
Klúčovým faktorom znižovania celkového objemu vývozu dreva a osobitne exportu do Nemeckej ríše a Protektorátu boli reštriktívne opatrenia štátu smerujúce k regulácii t’ažby, dodávok a cien dreva. Už v prvom roku existencie samostatného Slovenska, ked' vládne miesta aj výrobcovia vítali rast odbytu gul'atiny a využitie drevárskych závodov až na $85 \%$, začali sa ozývat' kritické hlasy požadujúce usmernenie produkcie a vývozu dreva. S kritikou vystúpili slovenské celulózky v memorande z 5. septembra 1939, ktoré adresovali Slovenskej lesnej a drevárskej rade. Poukázali na skutočnost', že najväčší podnik lesného hospodárstva Štátne lesy a majetky im na sledovaný rok zabezpečil iba 155 tis. $\mathrm{m}^{3}$ celulózového dreva, pričom ich výrobná spotreba sa pohybovala v rozmedzí 850 tis. až 1000 tis. $\mathrm{m}^{3}$ ročne. Príčinu videli v neúmernom odbyte suroviny pre účely drevospracujúceho priemyslu a exportu. Žiadali nové dodávky ihličnatej gul'atiny v objeme 255 tis. $\mathrm{m}^{3}$ do februára 1940 a stanovenie podmienok t’ažby, distribúcie a cenotvorby dreva na základe dohody všetkých zainteresovaných. Lesná a drevárska rada na čele $\mathrm{s}$ P. Zat'kom vyšla piatim celulózkam v ústrety. Nechala zistit' reálne zásoby gul'atiny pre ich potreby a na 29. januára 1940 zvolala poradu zástupcov slovenského drevárstva. Následne podala návrh ministerstvu hospodárstva na okamžitý zákaz vydávania povolení exportu ihličnatého dreva. Ministerstvo návrh čiastočne akceptovalo, ale vydávanie povolení exportu do krajín s hodnotnými devízami odmietlo zastavit'. Prax ukázala, že pod tlakom výrobcov a zahraničných odberatel'ov si ihličnaté drevo aj v roku 1940 udržalo najväčší až $56 \%$ podiel na objeme vývozu drevárskych produktov. Konkrétne vývoz ihličnatej gul'atiny klesol iba čiastočne zo 171 tis. t. na 136 tis. t. ${ }^{26}$

Výraznejšie zmeny v obmedzovaní exportu nastali až v rokoch 1941 - 1943 zároveň $\mathrm{s}$ formovaním vojnového hospodárstva a $\mathrm{s}$ budovaním systému štátno-monopolistických korporácií. Medzi ne bolo možné zaradit’ aj Lesnú a drevársku ústredňu pod vedením K. Kosljara. Ústredňa mala za úlohu zabezpečit' dodávky dreva pre domáci trh a zásobovanie obyvatel'stva. Preto k 1. novembru 1942 vydala piliarskym závodom príkaz, aby minimálne $30 \%$ svojej produkcie smerovali na domáci trh. ${ }^{27}$ Objektom reštrikcií sa opät' stal aj obchod s ihličnatým drevom. Nový pokus vyčlenit' dodávky ihličnatej gul'atiny najmä pre celulózky a zastavit’ jej únik za hranice uskutočnilo ministerstvo hospodárstva,

26 SNA, f. ÚPV 1939 - 1945, inv. č. 66, k. 89. Memorandum slovenských papierní a celulózok z 5. 9. 1939; SNA, f. ÚPV 1939 - 1945, inv. č. 66, k. 89. Správa Slovenskej lesnej a drevárskej rady na predsedníctvo vlády o riešení problému dodávok dreva celulózkam a o opatreniach na obmedzenie exportu celulózového dreva z 10. 2. 1940; Drevársky priemysel. In Slovenský priemysel, 1939, s. 19; Drevársky priemysel. In Slovenský priemysel, 1940, s. 18.

27 BArch Berlín, f. R 3701, zv. 399. Správa lesného atašé F. Wechselbergera na Ríšsky lesný úrad ministerskému radcovi $\mathrm{W}$. Wrabcovi o zavedení povinného $30 \%$ podielu dodávok dreva na domáci trh. 
ked’ vyhláškou č. 570 z decembra 1941 vydalo úplný zákaz exportu predmetnej suroviny. Ďalšou vyhláškou č. 571 obmedzilo jej dodávky piliarskym závodom. Vyhláška zakazovala pílam spracovávat' ihličnatú gul'atinu s priemerom menším ako $18 \mathrm{~cm}$. Všetka surovina s uvedeným priemerom mala byt' poskytnutá celulózkam. Od júna 1942 celá oblast' drevárstva, podobne ako d’alšie hospodárske odvetvia podliehala nariadeniam centrálnej štátno-monopolistickej inštitúcie Najvyššiemu úradu pre zásobovanie (NÚZ). Opatrenia NÚZ v drevárstve smerovali k prídelovému systému. Vyhláškou č. 498/1942 zaviedol povinnost' pravidelne hlásit' zásoby ihličnatého dreva vo všetkých podnikoch a obchody s ihličnatou surovinou podrobil schval'ovaciemu konaniu. Ďalšie opatrenia nasledovali v roku 1943, ked' NÚZ vyhláškou č. 438 zaviedol prídely ihličnatej gul'atiny na základe priemernej spotreby tejto suroviny $\mathrm{v}$ jednotlivých drevárskych podnikoch za roky 1938 - 1941. Dosah celého systému opatrení však mal svoje limity. Ihličnaté drevo ostávalo aj napriek obmedzeniam exportu dôležitou súčast'ou zahranično-obchodnej výmeny s Nemeckou ríšou a d’alšími krajinami. Trh s listnatým drevom bol štátno-monopolistickými zásahmi ovplyvnený len v oblasti cien a jeho export sa zvyšoval. Napríklad vývoz bukovej gul'atiny sa v rokoch 1941 - 1942 zvýšil o $40 \%{ }^{28}$

Neuralgickým bodom slovensko-nemeckých drevárskych obchodov bol vývoj cien, ktorý zaostával za vývojom cenovej hladiny drevárskych produktov na domácom a medzinárodnom trhu. Ceny jednotlivých komodít exportu slovenského dreva do Nemeckej ríše a Protektorátu boli stanovené zároveň s kontingentmi na rokovaniach Nemeckého výboru pre lesné a drevárske hospodárstvo Slovenska a Slovenskej lesnej a drevárskej rady na začiatku roka 1940 v Bratislave, d’alej v septembri 1940 v Trenčianskych Tepliciach a v máji a septembri 1941 v Piešt’anoch. V predchádzajúcom období rokov 1939 - 1940 sa podl’a správ nemeckých národohospodárov nakupovalo drevo podl'a cien určených podnikom Štátne lesy a majetky. Medzi rokovaniami platili pevné ceny a kontingenty. Dohodnuté ceny v zásade rešpektovali cenové rozpätia a stropy cien dreva stanovené slovenskými vládnymi orgánmi a inštitúciami. Rešpektované však boli len ceny, ktoré platili v čase jednotlivých rokovaní. Zmeny cien v období medzi rokovaniami sa v zahraničnom obchode s Nemeckou ríšou zohladňovali iba okrajovo alebo vôbec nie. Podobne to bolo aj v prípade kontingentov. Obmedzenia vývozu a iné reštriktívne opatrenia v obchode mohli byt' akceptované až na najbližších slovensko-nemeckých rokovaniach. Okrem toho, ceny stanovené administratívne vládnymi orgánmi a monopolnými inštitúciami ako Cenový úrad a neskôr NÚZ sa však spravidla značne odlišovali od reálneho vý-

28 Drevársky priemysel. In Slovenský priemysel, 1942, s. 18; Drevársky priemysel. In Slovenský priemysel, 1943, s. 18, 20. 
voja na slovenskom a medzinárodnom trhu, nehovoriac už o čiernom trhu s drevom, ktorý tiež existoval. Podl'a oficiálnych údajov vzrástli ceny vyvážaného dreva v priemere na tonu za roky 1939 - 1943 o $64 \%$, zatial' čo ceny dreva v slovensko-nemeckých obchodoch v priemere asi o $27 \% .^{29}$

Ked' sledujeme vývoj cien dreva na slovensko-nemeckých rokovaniach, zist’ujeme, že sa od oficiálnych údajov značne líšili. Zároveň boli vel'ké rozdiely vo vývoji cien jednotlivých druhov dreva. V porovnaní cien z prelomu rokov 1939 - 1940 a 1941 - 1942 zist'ujeme, že oficiálnemu údaju o priemernom zvýšení cien zodpovedal len vývoj v segmente ihličnatej gul'atiny, a to už počas uvedeného krátkeho obdobia dvoch rokov. Ceny stále žiadanejšej listnatej gul'atiny vzrástli za uvedené obdobie o $45 \%$ až $50 \%$, ceny ihličnatého reziva o $34 \%$ až $38 \%$, ceny listnatého reziva o $34 \%$ až $41 \%$. Nižší rast zaznamenalo iba palivové drevo asi o $22 \%$ a ihličnaté stolárske drevo o $15 \% .{ }^{30} \mathrm{~V}$ nasledujúcom období rokov 1942 - 1944 sa ceny vzhl'adom na vojnové potreby d'alej zvyšovali. Po zrušení Slovenskej lesnej a drevárskej rady boli ceny a kontingenty zo slovenskej strany dohadované členmi slovenského vládneho výboru, Slovenského výboru pre lesné a drevárske hospodárstvo a Slovenskej lesnej a drevárskej centrály. Na slovensko-nemeckých rokovaniach sa z oboch strán prehlbovalo napätie a tlak vzájomne protikladných požiadaviek. Od jesene 1941 prebiehal zápas o zvýšenie cien zo strany Slovenska a o zvýšenie kontingentov zo strany Nemecka. V rokoch 1942 - 1943 slovenský vládny výbor opakovane argumentoval tým, že ceny dreva na vnútornom trhu Slovenska rástli vzhl'adom na zvyšovanie výrobných nákladov podstatne rýchlejšie než ceny v slovensko-nemeckom obchode. Exportérom následne vznikali straty. Nemecký vládny výbor po viacerých urgenciách súhlasil s rastom cien. Na zasadnutí v máji 1943 však vystúpil s ostrou kritikou cenovej politiky Slovenska. Jeho predstavitelia tvrdili, že ceny dovážaného slovenského dreva už prekročili hladinu domácich cien na nemeckom aj slovenskom trhu. Pohrozili zvýšením cien nemeckých tovarov dovážaných na Slovensko. ${ }^{31} \mathrm{~V}$ skutočnosti bola cenová hladina v porovnaní s vý-

29 PA AA, f. GP, k. 207. Dohoda Slovenskej lesnej a drevárskej rady a Nemeckého výboru pre lesné a drevárske hospodárstvo z 11. 9. 1940 v Trenčianskych Tepliciach; PA AA, f. R 105 331. Dohoda Nemeckého výboru pre lesné a drevárske hospodárstvo a Slovenskej lesnej a drevárskej centrály z 18. 9. 1941 v Piešt’anoch; LÁNGOŠ, ref. 1, s. 18-19.

30 BArch Berlín, f. R 3701, zv. 396. Správa Ústredne pre lesné a drevárske hospodárstvo Protektorátu Čechy a Morava na Ríšsky lesný úrad zo 17. 3. 1942 o dovoze dreva zo Slovenska a vývoji cien slovenského dreva.

31 PA AA, f. GP, k. 210. Zasadnutie Slovenského lesného a drevárskeho výboru a Nemeckého výboru pre lesné a drevárske hospodárstvo 21. - 24. 9. 1942 v Bratislave; PA AA, f. R 105 331. Zasadnutie Slovenského lesného a drevárskeho výboru a Nemeckého výboru pre lesné a drevárske hospodárstvo 23. - 29. 3. 1943 v Bratislave; PA AA, f. R 105 331. Protokol zo šiesteho zasadnutia slovensko-nemeckých vládnych výborov 4. - 21. 5. 1943 v Bratislave. 
vozom do iných štátov výrazne nižšia. Napríklad v hlásení na Ríšsky lesný úrad, ktoré tiež pochádzalo z mája 1943, sa uvádzalo, že ceny rôznych druhov dreva v slovensko-talianskom obchode, dohodnuté medzi jednotlivými slovenskými a talianskymi firmami boli o 40 \% až 68 \% vyššie než priemerné ceny v slovensko-nemeckom drevárskom obchode. Daný stav odporoval nemecko-talianskej dohode z apríla 1942, podl'a ktorej mali ceny dreva importovaného do Talianska prevyšovat' priemer cien drevárskeho tovaru dovážaného do Ríše maximálne o $4 \%$. Taliansky trh bol za týchto podmienok pre slovenských vývozcov podstatne zaujímavejší než nemecký. ${ }^{32}$

Od polovice roka 1941 začali predstavitelia Nemecka stupňovat' tlak aj na zvyšovanie kontingentov surového a spracovaného dreva v exporte do Ríše a Protektorátu. Zástupcovia Slovenska poukazovali na obmedzené technické kapacity t’ažby a spracovania dreva, ktoré limitovali možnosti exportu. Východisko nachádzali v realizácii sl’ubovaných projektov na modernizáciu lesníctva a drevárstva. Vzhl'adom na potenciálne možnosti t’ažby a zabezpečenie vlastných potrieb Slovenska štátno-monopolistickými opatreniami, bol celkový nárast kontingentov v rokoch 1941 - 1943 len mierny a exportéri z dohodnutých objemov vývozu dodržali iba niektoré. Preto sa plnenie väčšiny kontingentov doháňalo nasledujúci rok. V reálnom vývoji exportu jednotlivých druhov dreva prevažovala stagnácia alebo pokles. Okrem postupných obmedzení vo sfére celulózového dreva a ihličnatého dreva sa podl’a správ Ústredného združenia slovenského priemyslu znižovali aj dodávky banského dreva a podvalov. Medzi problémové patrili tiež dodávky generátorového dreva a chemicky spracovaného dreva vo forme celulózy a dreveného uhlia. Práve v oblasti týchto nedostatkových komodít však narastali požiadavky zo strany Nemecka. Napríklad celkový vývoz podvalov, životne potrebných na rekonštrukciu systematicky ničených železníc, klesol v roku 1942 približne o tretinu, ale kontingent dohodnutý pre Nemeckú ríšu a Protektorát na roky 1943 - 1944 ostal na úrovni roka 1941. ${ }^{33}$ Bývalý minister hospodárstva G. Medrický uviedol vo svojich pamätiach prípad hrubého nátlaku nemeckej strany ohl'adne exportu strategicky dôležitého celulózového dreva, čiže tzv. vlákniny.

32 BArch Berlín, f. R 3701, zv. 399. Správa Ríšskeho lesného úradu na Zahraničný úrad v Berlíne z 31. 5. 1943 o vývoji cien dreva na slovensko-nemeckom a slovensko-talianskom trhu.

33 PA AA, f. R 105 331. Dohoda Nemeckého výboru pre lesné a drevárske hospodárstvo a Slovenskej lesnej a drevárskej centrály z 18. 9. 1941 v Piešt’anoch; PA AA, f. GP, k. 210. Zasadnutie Slovenského lesného a drevárskeho výboru a Nemeckého výboru pre lesné a drevárske hospodárstvo 21. - 24. 9. 1942 v Bratislave; PA AA, f. R 105 331. Zasadnutie Slovenského lesného a drevárskeho výboru a Nemeckého výboru pre lesné a drevárske hospodárstvo 23. - 29. 3. 1943 v Bratislave; PA AA, f. R 105 331. Príloha č. 1 Protokolu zo siedmeho zasadnutia slovensko-nemeckých vládnych výborov v septembri až októbri 1943; Príloha D Protokolu zo siedmeho zasadnutia slovensko-nemeckých vládnych výborov v septembri až októbri 1943; Drevársky priemysel. In Slovenský priemysel, 1942, s. 19-20. 
Nemecko žiadalo zvýšenie dodávok celulózového dreva o 100 tis. $m^{3}$ nad objem dohodnutého kontingentu. Iniciátorom nátlaku v zmysle uvedených požiadaviek mal byt' jeden z hlavných predstavitel'ov nemeckých drevárskych inštitúcií W. Parchmann. Podl'a ministra Medrického slovenská strana požiadavky odmietla. ${ }^{34}$

Vývoj celkovej štruktúry kontingentov za sledované roky možno zostavit' len vel'mi t’ažko pre nedostatok údajov a tiež v dôsledku rôznorodosti jednotiek, $\mathrm{v}$ ktorých bol export jednotlivých druhov dreveného tovaru udávaný. ${ }^{35} \mathrm{~K}$ dispozícii máme len celkové údaje o plánovaných kontingentoch vývozu do priestoru Nemeckej ríše a Protektorátu na rok 1944, ktoré vychádzali zo stavu dosiahnutého v roku 1943. Týmto si môžeme vytvorit’ predstavu o maximálnych objemoch exportu jednotlivých drevárskych komodít, aj ked' len $v$ teoretickej rovine, lebo máloktorý z nich bol dodržaný. Podl'a dohody malo Slovensko vyviezt' 45 tis. $\mathrm{m}^{3}$ ihličnatej a 99 tis. $\mathrm{m}^{3}$ listnatej gul'atiny, 60 tis. $\mathrm{m}^{3}$ banského dreva, 450 tis. $\mathrm{m}^{3}$ ihličnatého a 86 tis. $\mathrm{m}^{3}$ listnatého reziva, 3,5 tis. t. dubovej kôry, 1100 vagónov kôry iných druhov stromov, 600 vagónov pilín, d’alej palivové drevo v hodnote 100 tis. RM a 550 tis. kusov podvalov.

Z uvedeného vyplýva, že dohody o kontingentoch aspoň čiastočne rešpektovali obmedzenia vývozu ihličnatej gul'atiny, zatial' čo podiel listnatého dreva v exporte gul'atiny rástol a v rokoch 1943 - 1944 mal dosiahnut' okolo $70 \%$. Vývoz ihličnatého reziva však bol napriek obmedzeniam stále dost' vysoký, podobne ako aj podvalov a niektorých d'alších komodít. Do letných mesiacov roka 1944 sa zmluvné strany pokúšali v rámci dobových podmienok a hospodárskych možností kontingenty dodržiavat'. Vojensko-politický a hospodársko-politický vývoj od konca augusta 1944 však d’alšie plnenie záväzkov znemožnil. Kontingenty museli byt' modifikované a organizáciu vývozu dreva de facto prevzalo velenie okupačných nemeckých jednotiek a exponenti hospodárskych záujmov Nemeckej ríše na Slovensku. ${ }^{36}$

V rokoch 1942 - 1944 kulminoval dopyt po dovoze dreva zo Slovenska v Nemeckej ríši, Protektoráte, ako aj v d’alších krajinách. Napriek tomu, že slovenský

34 MEDRICKÝ, Gejza. V práci za povznesenie národa. Spomienky ministra hospodárstva Slovenskej republiky 1939 - 1945. Bratislava: Post Scriptum, s.r.o., 2017, s. 145-146. ISBN 9788089567744.

35 Množstvo dodávaného dreva mohlo byt' stanovené napríklad v plnometroch (plm), ktoré sa rovnajú kubickým metrom $\left(\mathrm{m}^{3}\right)$, d’alej v priestorových metroch, ktoré sú bud' skladané $(\mathrm{prm}=70 \%$ drevo $+20 \%$ vzduch) alebo sypané (prms $=50 \%$ drevo $+50 \%$ vzduch), d'alej $\mathrm{v}$ kusoch, tonách, vagónoch, prípadne $\mathrm{v}$ hodnotovom vyjadrení $\mathrm{v}$ ríšskych markách alebo slovenských korunách.

36 PA AA, f. R 105 331. Príloha č. 1 Protokolu zo siedmeho zasadnutia slovensko-nemeckých vládnych výborov v septembri až októbri 1943; Príloha č. 5 Protokolu zo siedmeho zasadnutia slovensko-nemeckých vládnych výborov; PA AA, f. R 105 331. Príloha O Protokolu z ôsmeho zasadnutia slovensko-nemeckých vládnych výborov v apríli až júni 1944. 
štát bol len jedným z viacerých dodávatel’ov drevárskych tovarov do Nemeckej ríše a kl’účovú úlohu plnil iba v zásobovaní Protektorátu, záujem o slovenské drevo na pôde Ríše neustále rástol. Svedčili o tom mnohé intervencie a žiadosti nemeckých drevospracujúcich firiem a iných odberatel'ov adresované na nemecké vyslanectvo v Bratislave lesnému atašé $\mathrm{F}$. Wechselbergerovi alebo na Ríšsky lesný úrad a Ríšske ministerstvo hospodárstva W. Wrabcovi a iným úradníkom o zvýšenie alebo aspoň dodržanie zmluvne stanovených dodávok dreva zo Slovenska a pochopitel'ne aj o zníženie cien. Slovenské a nemecké firmy mali v rámci celoštátnych kontingentov a cien dohodnuté vlastné čiastkové kontingenty a cenové rozpätie.

Obšírne správy so žiadost’ou o nápravu zaslal na Ríšsky lesný úrad napríklad majitel' nemeckej firmy R. Reichelt and Co. Neugersdorf, ${ }^{37}$ ktorý dovážal listnatú gul'atinu, brezové tyče a ihličnaté rezivo. V liste z marca 1943 poukázal na skutočnost', že vzhl'adom na rastúci dopyt po slovenskom dreve na nemeckej strane a neúmerne vysokú cenovú hladinu na Slovensku nebolo možné realizovat' zmluvne potvrdené dodávky a ceny. Slovenský trh bol údajne otvorený až 240 importérom z Ríše a početným nemeckým drevárskym maklérom, ktorí tlačili na vývoj dopytu aj cien. St’ažoval sa aj na pretrvávajúci vplyv židovských manažérov, d’alej pôsobiacich $\mathrm{v}$ arizovaných firmách. Títo údajne bojkotovali nemeckých odberatel'ov a uprednostňovali protektorátne firmy. Konkrétne spomínal tri žilinské drevárske firmy Fasko a spol., Malobický a Bardaky a spol. ${ }^{38}$ V nasledujúcom roku v liste z júna 1944 riešil ministerský radca W. Wrabec a jeho referenti žiadost' drevárskej firmy Lohbeck and Co. Düsseldorf o zvýšenie ročného kontingentu na dovoz ihličnatého reziva zo Slovenska v hodnotovom vyjadrení z 300 tis. na 360 tis. RM. Celkový spoločný kontingent uvedenej firmy na dovoz ihličnatého reziva zo Švédska a Fínska pritom len nepatrne prevyšoval 500 tis. RM. ${ }^{39}$

* Štúdia bola vypracovaná v rámci riešenia projektov APVV-16-0047: Od denára k euru. Fenomén peñazí v dejinách Slovenska od stredoveku po súčasnost' na Historickom ústave SAV Bratislava a VEGA 2/0043/16: Vzostup a pád hospodárskeho vývoja Slovenska 1942 - 1945 na Historickom ústave SAV Bratislava a na Katedre histórie Filozofickej fakulty UMB Banská Bystrica.

37 Dnes súčast' mesta Ebersbach-Neugersdorf v Sasku v Lužicko-srbskej oblasti.

38 BArch Berlín, f. R 3701, zv. 399. List firmy R. Reichelt and Co. Neugersdorf na Ríšsky lesný úrad zo 16. 3. 1943.

39 BArch Berlín, f. R 3701, zv. 399. List W. Wrabca a jeho referentov na Ríšskom lesnom úrade firme Lohbeck and Co. Düsseldorf z 30. júna 1944. 


\section{DIE ROLLE DEUTSCHLANDS IN DER HOLZINDUSTRIE \\ DER SLOWAKEI 1939-1945. \\ INSTITUTIONELLE ENTWICKLUNG UND HANDEL MIT HOLZ}

Forstwirtschaft und Holzindustrie besaßen in den zwischen der Slowakei und nationalsozialistischem Deutschland 1939-1945 geführten Wirtschaftsbeziehungen eine strategische Bedeutung. In Bezug auf Mittel- und Südosteuropa nahm die slowakische Holzindustrie in den Plänen des Deutschen Reiches den erstrangigen Platz bereits ab der ersten Hälfte der 1930er Jahre. Eine wichtige Rolle spielten Rundholz-Lieferungen wie auch der Export der Erzeugnisse der slowakischen Holzindustrie in Form von SägewerkHalbfabrikaten und Fertigprodukten. Deutsche Regierungsstellen entsandten ihre speziell auf Forstwirtschaft und Holzindustrie orientierten Vertreter in die Slowakei. Die slowakisch-deutschen Beziehungen entwickelten sich im Bereich der Holzindustrie in zwei Richtungen: als Handel mit Holz und als Holzindustrie, in die allmählich das reichsdeutsche Kapital durchdrang. Bis 1942 stieg der Anteil am Gesamtwert des slowakischen Exports im Handel mit rohem und verarbeitetem Holz auf 29 Prozent. Dabei wurden etwa 70 bis 80 Prozent der Gesamtwertes des slowakischen Exports des Rundholzes und Holzerzeugnisse ins Gebiet des Deutschen Reichs einschließlich des Protektorats Böhmen und Mähren wurden geliefert. Trotz eines durch Deutschland ausgeübten Drucks gelang es jedoch den slowakischen Volkswirten, den Holzexport durch gesetzliche und andere Maßnahmen stufenweise zu senken und die Holzausfuhr auch in andere Länder außerhalb des Deutschen Reiches zu besseren Preisbedingungen umzusetzen.

PhDr. Ludovít Hallon, DrSc.

Historický ústav SAV

P. O. Box 198, Klemensova 19, 81499 Bratislava

e-mail: histhall@savba.sk

Doc. PhDr. Peter Mičko, PhD.

Katedra histórie, Filozofická fakulta Univerzita Mateja Bela

Tajovského 40, P.O.BOX 263, 97401 Banská Bystrica

e-mail: peter.micko@umb.sk

PhDr. Miroslav Sabol, PhD.

Historický ústav SAV

P. O. Box 198, Klemensova 19, 81499 Bratislava

e-mail: histmiki@savba.sk 